\title{
Employment and decent work for the population: interdisciplinary legal research
}

\author{
Yulia Sergeevna Sergeenko ${ }^{11}$, Elena Valeryevna Kombarova ${ }^{1}$, Marina Vladimirovna \\ Rybkina $^{2}$, Natalya Vladimirovna Bobrakova ${ }^{3}$, and Olga Vladimirovna Averyanova ${ }^{4}$ \\ ${ }^{1}$ Saratov State Academy of Law, Department of Employment Law, Saratov, Russia \\ ${ }^{2}$ Saint-Petersburg State Economic University, Department of Constitutional Law named after \\ Professor Isaac E. Farber, Saint Petersburg, Russia \\ ${ }^{3}$ Pushkin Leningrad State University, Department of Civil and Corporate Law, Saint Petersburg, \\ Russia \\ ${ }^{4}$ S. M. Kirov Military Medical Academy, Department of Humanities and Socio-Economic Disciplines, \\ Saint Petersburg, Russia
}

\begin{abstract}
The objective of the research is to develop the proposals for stabilization of the number of working places, decrease of unemployment in the countries, provision of guarantees in the period of the temporary unemployment. The methodological base of the research is the legislation framework; scientific publications of the scientists from different countries; statistical data of the United Nation Organization, after analysis of which the authors created and offered the complex of "steps" for support, correction and increase of the level of decent working places for the people on Earth. Also the authors used the comparison method in the paper. After collection of data of the decrease and increase of the number of working places in the countries in the period of instability and emergency situation, using the probability and statistical method the authors revealed the consequences of the use of the developed proposal by the states. During the study of employment in the world the authors came to the conclusion about the necessity to create a united international employment base of the citizens of any country. It shall contain the vacant jobs all over the world, distributed according to the branches, professions and this will facilitate the search of job and the further conclusion of the labor contract between the employee and the employer. The novelty of the research is the proposed legal lines of the activity of the states in the field of employment (increased unemployment benefit rate, establishment of the part-time work, etc.).
\end{abstract}

Keywords: employment, work, labour, unemployment

\section{$1 \quad$ Introduction}

Employment and decent work for the citizens is one of the important directions of every state's policy. The main laws of the states contain the articles guaranteeing the freedom of labor and unemployment protection. The quality and life expectancy of citizens and their families depend upon how well they are provided with the decent work (social status in the

${ }^{1}$ Corresponding author: iulya.sergeenko@yandex.ru 
society (food, medical treatments, education, living standards)). Therefore the changes that took place in the market of employment in the 21 century, emergency situations that impacted the citizens with decent jobs, unstable economic situation became the prerequisites of the research. Many papers of scientists in this field confirm the necessity of a profound study of this direction, creation of a united complex of measures of keeping balance at the level of the labor market in the world.

The eighth objective of the sustainable development of the UN Organization is to "Promote inclusive and sustainable economic growth, employment and decent work for all". Therefore one of the main elements of life of every person on Earth is his profession, occupation, mission in the professional activity. After finding it (profession) the citizen realizes and implements his talent and mission receiving the salary for it. However, in the course of a lifetime there are ups and downs, unfortunately, and they do not always depend upon him. The economic instability, emergency situations (the most acute issue now (epidemics, epizootics, catastrophes)) have a great impact on the employment of the population of the countries.

The international scientific society is concerned by this problem and this is confirmed by the significant number of the published articles, monographies, textbooks referred to this issue. Thus, for example, according to the opinion of Andres A. Agudelo-Suarez, Mary Yanet Vargas-Valencia, Jonny Vahos-Arias, Gladis Ariza-Sosa, Wilder J. Rojas- Gutiérrez, Elena Ronda- Pérez: "The following characteristics of precarious employment were found: instability in employment conditions, work in the informal or submerged economy, limited empowerment, absence of social benefits, high vulnerability, low income, and a limited capacity for exercising labor rights. This situation affects mental health conditions, access to health services, and the presence of risks due to the work they perform" [1].

Andrew Taeho Kim, Chang Hwan Kim, Scott E. Tuttle, Yurong Zhang believe that "The unemployment rate has sharply increased as a result of the lockdown associated with the spread of COVID-19. The negative effect of the lockdown is more conspicuous among the less-educated workers than the highly-educated workers. Because Asian Americans are more likely to have a bachelor or higher degree than any other racial group, they are expected to be relatively immune to the drop in employment unless the detrimental impact of the lockdown is severer for Asian Americans" [2].

In their works the scientists studied:

- Vocational support [3];

- differences in employment between men and women [4];

- $\quad$ efficient employment [5];

- $\quad$ quality of employment of population [6];

- $\quad$ proficiency enhancement of top management of enterprises [7];

- $\quad$ security digitalization [8].

As a result of the study of theoretical base, the scientists came to the conclusion of the absence of the united international employment base for the citizens of any country, creation and use of which in the large branches of industry can help avoiding the fluctuations of the population employment in the countries. In their work the authors use the scientific hypothesis that expresses the result (base) by means of confirmation of the legislation, statistics, scientific works. The objective of the article is to develop the complex of directions to improve the employment and provide the decent work for citizens. The task is to develop a complex system to overcome the employment emergency situations in the countries.

\section{Methods}


Using the legislation base, scientific works from different countries, statistical data and after studying the latest data of the UN Organization the researchers created and offered the complex of "steps" for support, correction and increase of the level of decent working places for the people on Earth. Also, the authors used the comparison method in the paper, they collected the data of decrease and increase of number of working places in the countries in the period of instability and emergency situation. Using these results and by means of the probability and statistical method, the scientists revealed the consequences of the use of the developed proposal by the states.

\section{$3 \quad$ Results}

The lifetime and life quality of people is the most important for the leaders of our countries. The employment guarantees and unemployment protection are enshrined in the main laws of the states, for example, Article 37 of the Constitution of the Russian Federation [9], Article 24 of the Constitution of the Republic of Kazakhstan [10], the Article 41 of the Constitution of the Republic of Belarus [11].

- To comply with these guarantees and preserve the stabile life of people the interaction of the leaders of the states is required as well as of the head of the plants, companies, organizations when implementing the legal directions in the employment sphere:

- to establish the increased unemployment benefit (in case of emergency situations there is a necessity to increase the compensations to the fired employees and those registered as unemployed until the stability of the labor market, elimination of the absence of revenues, search of work);

- to establish the part-time working day, established by the legislation for the required period for the enterprise to preserve the working places (for example, the Article 93 of the Labor Code of the Russian Federation [12]);

- creation of the united international unemployment base for the citizens of any country.

The scheme of the international base looks as shown in figure 1.

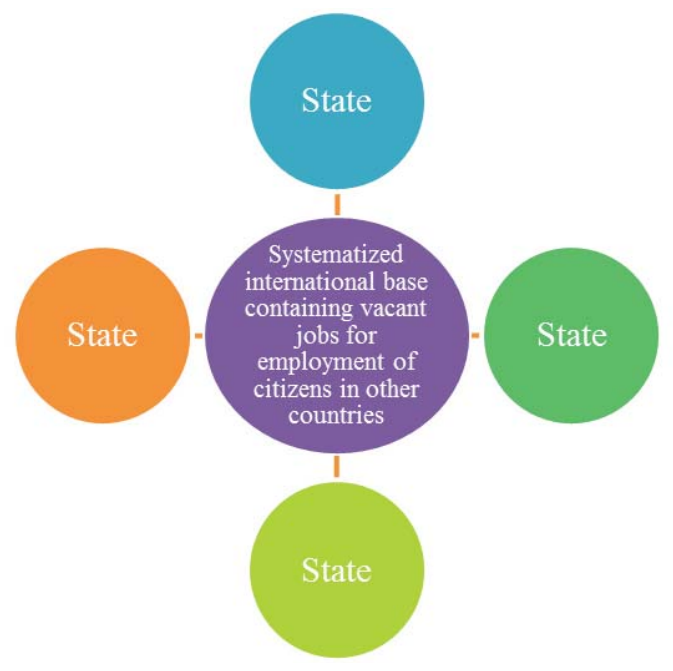

Fig. 1. The structure of the international base. 
The base shall contain the vacant, free working places distributed according to the branches (for example railways, energy, food industry, agriculture, etc.). When applying to this base it will be easier for workers to find the occupational work (work can be made offline or online depending upon the requirements of the employer).

\section{Discussion}

"In 2017 the global unemployment level was 5.6\% and in $2000-6.4 \%$ " [13], and "In the period from 2006 until 2030 it will require 470 mln working places for the new participants of the global labor market" [13]. According to the "Report of objectives in the field of sustainable development" one of the main conclusions is "According to some estimations $71 \mathrm{mln}$ people in 2020 will live below the extreme poverty line - the number of the poverty population on the planet will grow for the first time since 1998. Due to the loss of revenue, limitation of the social security and growth of prices even those can face the poverty and hunger who earlier were safe" [14], and also "The result of the crisis is the underemployment and unemployment and that means about 1.6 bln workers involved in the informal fields of activity and already being in the vulnerable position can suffer seriously: according to some estimations during the first month of crisis their revenues decreased at $60 \%$ " [14]. Therefore the provision of the decent work and employment is a global issue for the world. Using the proposals of the authors of the article we can support each other in the emergency situations and protect against the job loss. Definitely, it will require time, international negotiations and discussions when the work of this new structure of the additional work provision for the citizens of different countries and material costs for implementation shall be executed in detail. But all these efforts will give a positive result for the citizens and their states as well as for the world community in general.

\section{Conclusion}

As a result of the performed research, the authors proposed the legal directions of the states: increase of unemployment benefits for the periods of economic crisis and emergency situations in the world and also the creation of the united base of data divided according to the branches for simple and convenient search of the suitable work. Certainly, the recommendations require further development, systematization and possibly making some amendments and additions, improving this base of data up to the high level of work. When analyzing the situation in the world since 2000 we can observe the ups and downs of the unemployment level of the population and provision of the employees with the decent working places that are related to the financial fluctuations, mass diseases of people that is irrefutable proof of the urgency of taking measures to improve the living standards of the citizens in the labor sphere.

\section{References}

1. A.A. Agudelo-Suárez, et al., Colombia J. Migr. Health 1-2, 100009 (2020). https://doi.org/10.1016/j.jmh.2020.100009

2. A.T. Kim, C.H. Kim, S.E.Tuttle, Y. Zhang, Asian Amer. Employment Res. Soc. Stratif. Mobil. 71, 100563 (2020). https://doi.org/10.1016/j.rssm.2020.100563

3. V.M. Marc, J. Lanovaz, Res. Autism Spect. Disord. 82, 101741 (2021). https://doi.org/10.1016/j.rasd.2021.101741 
4. W. Marcel, et al., Arch. Phys. Med. Rehabil. 101(12), (2020). https://doi.org/10.1016/j.apmr.2020.05.027

5. D.S. Saralinova, Tend. Devel. Sci. Edu. 66-2, 144-147 (2020). https://doi.org/10.18411/lj-10-2020-81 idsp: ljournal-10-2020-81

6. I.A. Ryskulbekov, Zh.E. Emurkanova, Bul. Osha State Univ. 1-1, 266-273, (2020)

7. E.N. Abanina, et al., IOP Conf. Series: Mater. Sci. Engin. 582, 012032 (2019). doi:10.1088/1757-899X/582/1/012032

8. Yu.S. Sergeenko, et al., IOP Conf. Series: Earth Environ. Sci. 543, 012001 (2020). doi:10.1088/1755-1315/543/1/012001

9. Konstitutsiya Rossiiskoi Federatsii (prinyata vsenarodnym golosovaniem 12 dekabrya 1993 g. s izmeneniyami, odobrennymi v khode obshcherossiiskogo golosovaniya 01 iyulya 2020 g.) [Constitution of the Russian Federation (accepted by the nation-wide vote on December 12, 1993 with amendments approved by the All-Russian vote on July 01, 2020]. Accessed on: June 30, 2021. [Online]. Available: http://www.consultant.ru/document/cons_doc_LAW_28399/5e37b9644c66582efdaf76 2a109a281bf999c28d/

10. Konstitutsiya Respubliki Kazakhstan (prinyata vsenarodnym referendumom 30 avgusta 1995 g.) [Constitution of the Republic of Kazakhstan (accepted by the nation-wide vote on August 30, 1995)]. Accessed on: March 14, 2021. [Online]. Available: https://www.akorda.kz/ru/official_documents/constitution

11. Konstitutsiya Respubliki Belarus (s izmeneniyami i dopolneniyami, prinyatymi na respublikanskikh referendumakh 24 noyabrya 1996 g. i 17 oktyabrya 2004 g.) [Constitution of the Republic of Belarus (wit at the Republican votes $h$ amendments and additions accepted at republican referendums on November 24, 1996 and on October 17, 2004)]. Accessed on: June 30, 2021. [Online]. Available: https://pravo.by/pravovaya-informatsiya/normativnye-dokumenty/konstitutsiya-respubl iki-belarus/

12. Trudovoi kodeks Rossiiskoi Federatsii ot 30 dekabrya 2001 g. № 197-FZ (red. ot 29.12.2020) [Labor Code of the Russian Federation dd December 30, 2001 No. 197-FZ (rev. dd 29.12.2020)]. Accessed on: June 30, 2021. [Online]. Available: http://www.consultant.ru/document/cons_doc_LAW_34683/4fc377218364ee95162e6c $077045035 \mathrm{~d} 75 \mathrm{c} 92 \mathrm{c} 6 \mathrm{~d} /$

13. Tseli v oblasti ustoichivogo razvitiya. Tsel 8: Sodeistvie postupatelnomu, vseokhvatnomu i ustoichivomu ekonomicheskomu rostu, polnoi i proizvoditelnoi zanyatosti i dostoinoi rabote dlya vsekh [Objectives in the field of sustainable development. Goal 8: Promote sustained, inclusive and sustainable economic growth, full and productive employment and decent work for all]. Accessed on: June 30, 2021. [Online]. Available: https://www.un.org/sustainabledevelopment/ru/economic-growth/

14. Doklad o tselyakh v oblasti ustoichivogo razvitiya [Report of the objectives in the field of sustainable development] Accessed on: June 30, 2021. [Online]. Available: https://www.un.org/sustainabledevelopment/ru/progress-report/ 